\title{
RANCANG BANGUN ALAT DESALINASI AIR LAUT TENAGA SURYA SISTEM PASIF KEMIRINGAN GANDA DENGAN AIR SEBAGAI PENDINGIN KACA LUAR
}

\author{
Joel P. Nababan ${ }^{1 *}$, Himsar Ambarita ${ }^{2}$, Andianto Pintoro ${ }^{3}$, Farel H. Napitupulu ${ }^{4}$ \\ ${ }^{1,2,3,4}$ Departemen Teknik Mesin, Fakultas Teknik, Universitas Sumatera Utara \\ Email: joelphanter7@gmail.com
}

\begin{abstract}
Fresh water plays a role and is responsible for life. The need for fresh water continues to increase due to its use in various fields of life, such as agriculture, industry and population. To prevent water shortages, it is very important to show the gap between the demand and supply of drinking water by developing water purification technology. Solar power / solar energy (renewable energy sources) in the form of distillation is one of the most promising, simple, and economical technologies for the purification of salt and brackish water. double slope passive system with the addition of water-cooled glass outside with water diluted by a solar-powered DC pump from photovoltaics with no outer glass cooler. In this work, passive double slope desalination with a basin area of $1,932 \mathrm{~m}^{2}$ with a glass surface of $1 \mathrm{~m}^{2}$ with two pieces with a glass thickness of $3 \mathrm{~mm}$ and a glass tilt angle of $15^{\circ}$. Surface water from a base of $20 \mathrm{~mm}$ and tested for 7 days starting at 08.00-18.00 WIB. The results of the comparison of the production of fresh water from the two tools show the desalination tool productivity with the addition of the outer glass cooling water is higher than the desalination tool without external glass cooler.
\end{abstract}

\begin{abstract}
Abstrak
Air bersih memegang peranan dan bertanggung jawab atas kehidupan. Kebutuhan akan air bersih terus meningkat karena penggunaannya di berbagai bidang kehidupan,seperti bidang pertanian, industri, dan populasi. Untuk mencegah terjadinya kekurangan air, sangat penting untuk menunjukkan kesenjangan antara permintaan dan pasokan air minum dengan mengembangkan teknologi pemurnian air. Tenaga surya/ energi matahari (sumber energi terbarukan) dalam bentuk penyulingan adalah salah satu teknologi yang paling menjanjikan, sederhana, dan ekonomis untuk pemurnian garam dan air payau Dalam penelitian skripsi ini, secara eksperimental dan teoritis dibahas mengkaji dan membandingkan teknologi penyulingan air laut / desalinasi sistem pasif kemiringan ganda dengan penambahan air pendingin kaca bagian luar dengan air dilairkan oleh pompa DC bertenaga surya dari photovoltaic dengan tanpa pendingin kaca luar. Dalam pekerjaan ini, desalinasi kemiringan ganda pasif dengan luas wilayah cekungan seluas $1.932 \mathrm{~m} 2$ dengan permukaan kaca $1 \mathrm{~m} 2$ dengan dua potong dengan ketebalan kaca $3 \mathrm{~mm}$ dan sudut kemiringan kaca $15^{\circ}$. Permukaan air dari dasar $20 \mathrm{~mm}$ dan diuji selama 7 hari dimulai pukul 08.00-18.00 WIB. Hasil perbandingan produksi air bersih dari kedua alat menunjukkan produktivitas alat desalinasi dengan penambahan air pendingin kaca bagian luar lebih tinngi dibandingkan alat desalinasi tanpa pendingin kaca luar.
\end{abstract}

\section{PENDAHULUAN}

Air bersih sangat dibutuhkan manusia dalam kehidupan sehari-hari, mulai kebutuhan air untuk minum sampai kebutuhan lain seperti memasak, mencuci mandi dan lainnya serta karena peningkatan taraf hidup manusia. Saat ini sumber air bersih yang dapat diperoleh dari mata air, sungai, danau, laut, namun sumber air saat ini sebagian besar sudah terkontaminasi zat kimia dan beracun yang berbahaya untuk manusia seperti polusi udara yang menyebabkan air hujan bercampur dengan zat-zat asap industri dan asap kendaraan. Dalam penelitian ini, akan dilakukan perbandingan produktivitas air bersih yang dihasilkan alat desalinasi dengan penambahan air sebagai pendingin kaca luar dengan alat desalinasi tanpa pendingin kaca luar.

\section{TEORI DASAR}

\subsection{Energi Surya}


Matahari merupakan salah satu sumber daya yang dapat diperbarui dengan ketersediaan yang melimpah dengan memancarkan energi radiasinya.

Salah satu potensi energi radiasi surya terbanyak dalam sebuah negara adalah Indonesia, dengan lokasi geografis yang terletak di daerah khatulistiwa yang menyebabkan Indonesia beriklim tropis dengan mengalami dua fase setiap tahunnya, yakni musim hujan dan musim kemarau. Nilai potensi energi radiasi surya di Indonesia adalah $16 \mathrm{MJ} /$ hari $[1,2]$.

Beberapa istilah yang biasanya dijumpai pada perhitungan radiasi adalah[3, 4]:

1. Massa udara $(m)$

Massa udara adalah perbandingan massa udara sampai ke permukaan bumi pada posisi tertentu dengan massa udara yang dilalui sinar jika matahari tepat pada posisi zenit. Artinya pada posisi tegak lurus (zenit $=0$ ) nilai $m=1$, pada sudut zenith $60^{\circ}, m=2$. Pada sudut zenith dari $0-70^{\circ}$, dirumuskan:

$$
m=\frac{1}{\cos \theta_{z}}
$$

Keterangan:

$m$ = massa udara

$\theta_{z}=$ sudut zenith

2. Radiasi beam

Radiasi beam adalah radiasi energi dari matahari yang tidak dibelokkan oleh atmosfer. Istilah ini sering disebut dengan radiasi langsung (direct solar radiation).

3. Radiasi difusi

Radiasi difusi adalah radiasi energi surya dari matahari yang telah dibelokan atmosfer.

4. Radiasi total

Radiasi total adalah jumlah beam dan diffuse radiation.

5. Laju radiasi $\left(\mathrm{W} / \mathrm{m}^{2}\right)$

Laju radiasi adalah laju radiasi yang diterima suatu permukaan persatuan luas permukaan tersebut Solar Irradiance biasanya disimbolkan dengan G. Dalam bahasa Indonesia besaran ini biasanya disebut dengan Intensitas radiasi.

\section{Irradiation atau Radian Exposure $\left(\mathrm{J} / \mathrm{m}^{2}\right)$}

Jumlah energi radiasi (bukan laju) yang diterima suatu permukaan dalam interval waktu tertentu. Besaran ini didapat dengan mengintegralkan $G$ pada interval waktu yang diinginkan, misalnya untuk 1 hari biasa disimbolkan $H$ dan untuk 1 jam biasa disimbolkan $I$.

7. Jam Matahari (Solar Time)

Jam matahari adalah waktu yang berdasarkan pergerakan semu matahari di langit pada tempat tertentu. Jam matahari (disimbolkan ST) berbeda dengan penunjukan jam biasa (standard time, disimbolkan STD). Persamaannya adalah:

$$
S T=S T D \pm 4\left(L_{s t}-L_{l o c}\right)+E
$$

Keterangan:

$S T \quad=$ jam matahari

$S T D=$ jam standard 
$L_{s t} \quad=$ meridian untuk waktu daerah setempat, sementara

$L_{l o c}=$ derajat bujur daeah yang diukur.

Dimana $E$ adalah persamaan waktu yang dihitung dengan persamaan Spencer, 1981:

$E=229,2(0,000075+0,00186 \cos B-0,032077 \sin B-0,014615 \cos 2 B-0,04089$

$\sin 2 B)$

Keterangan:

$E=$ persamaan waktu

$B=$ variable hari

Dimana, $B$ diperoleh dengan menggunakan persamaan:

$$
B=(n-1) \frac{360}{365}
$$

Keterangan:

$B$ = variable hari

$n=$ nilai urutan hari dalam satu tahun

\subsection{Perpindahan Panas}

- Perpindahan Panas Konduksi

Perpindahan panas konduksi adalah perpindahan panas yang melalui media hantaran solid atau padat.

$$
q=k \cdot A \cdot \frac{\Delta T}{x} .
$$

Keterangan:

$q$ = laju perpindahan panas konduksi (W)

$A=$ luas penampang dimana panas mengalir $\left(\mathrm{m}^{2}\right)$

$\Delta T=$ perubahan temperatur $(\mathrm{K})$

$k=$ konduktivitas termal $(\mathrm{W} / \mathrm{m} . \mathrm{K})$

$x=$ tebal masing-masing pelat $(\mathrm{m})$

- Perpindahan Panas Konveksi

Perpindahan panas konveksi adalah perpindahan panas akibat adanya media perantara berupa gerakan fluida atau zat alir.

$$
q=k \cdot A \cdot \Delta T
$$

Keterangan:

$q$ = laju perpindahan panas konveksi (W)

$A=$ luas penampang dimana panas mengalir $\left(\mathrm{m}^{2}\right)$

$\Delta T=$ perubahan temperatur $(\mathrm{K})$

$h=$ koefisien perpindahan panas konveksi $(\mathrm{W} / \mathrm{m} . \mathrm{K})$

- Perpindahan Panas Radiasi

Perpindahan panas radiasi adalah perpindahan panas yang tidak membutuhkan media perantara baik itu solid ataupun fluida.

Energi yang ditransfer dengan radiasi adalah yang tercepat (secepat kecepatan cahaya) dan dapat terjadi di ruangan vakum.

Perpindahan panas netto secara radiasi termal diantara dua badan ideal (hitam) diberikan oleh Gray, 1974.

Persamaan Umum Radiasi:

$$
q=\sigma \cdot A \cdot\left(T_{1}^{4}-T_{2}^{4}\right) .
$$

Dalam praktik kolektor surya, permukaan bukan pemancar ataupun penyerap yang sempurna dari radiasi termal. Permukaan kelabu semacam ini ditandai oleh fraksi-fraksi dari jumlah ideal yang dipancarkan dan diserap. 

1995.

Perpindahan panas radiasi antar pelat penyerap dengan kaca dirumuskan oleh Jansen,

$$
q=\frac{\sigma \cdot A \cdot\left(T_{1}{ }^{4}-T_{2}{ }^{4}\right)}{\frac{1}{\varepsilon_{1}}+\frac{1}{\varepsilon_{2}}-1}
$$

Keterangan:

$q$ = laju perpindahan panas radiasi (W)

$\varepsilon=$ emisivitas bahan

$A=$ luas penampang dimana panas mengalir $\left(\mathrm{m}^{2}\right)$

$\sigma=$ konstanta Stefan-Boltzman $\left(5,67 \times 10^{-8} \mathrm{~W} / \mathrm{m}^{2} \mathrm{~K}\right)$

$T_{1}=$ temperatur permukaan bidang satu $(\mathrm{K})$

$T_{2}=$ temperatur permukaan bidang dua $(\mathrm{K})$

Sementara itu perhitungan fraksi-fraksi radiasi pada suatu permukaan yang terkena radiasi matahari yaitu (Holfman, 1986):

a. Radiasi yang menyentuh permukaan bidang satu per satuan luas penampang:

$$
\frac{q}{A}=\frac{k L}{x}\left(T_{2}-T_{1}\right)+\frac{q}{A}=E b_{1}-F_{12} . J_{21}
$$

Keterangan:

$\frac{q}{A} \quad=$ radiasi yang mengenai permukaan bidang persatuan luas penampang $\left(\mathrm{W} / \mathrm{m}^{2}\right)$

$\frac{q}{A} \quad=$ radiasi matahari $\left(\mathrm{W} / \mathrm{m}^{2}\right)$

$E b_{1}=$ fraksi radiasi pada permukaan satu $(\mathrm{W} / \mathrm{m} 2)$

$=\sigma \cdot T_{1}^{4}$

$F_{12}=$ fraksi radiasi antara bidang satu dan dua

$J_{21}=$ radiosivitas radiasi permukaan dua terhadap permukaan satu

\subsection{Teori Dasar Desalinasi}

Desalinasi adalah prosedur fisik untuk memisahkan kelebihan garam terlarut dari air, payau dan air laut, atau larutan garam berair untuk mengumpulkan air isi dengan kadar garam rendah untuk penggunaan yang sesuai, seperti minum, industri, farmasi, kota, atau air rumah tangga.

Desalinasi adalah prosedur industri murni dan sistem energi intensif terlepas dari prosesnya, mengurangi biaya energi sebagai masalah ekonomi utama [5].

\subsubsection{Desalinasi Tenaga Surya Sistem Pasif}

Energi surya ditemukan paling cocok untuk memasok energi yang dibutuhkan untuk proses desalinasi baik dalam bentuk energi panas, energi mekanik atau energi listrik. Sistem distilasi tenaga surya telah dipelajari, dirancang dan digunakan di seluruh dunia. Sistem distilasi tenaga surya dikategorikan menjadi sistem pasif dan aktif.

Penyuling tenaga surya adalah prosedur yang menggunakan radiasi matahari secara langsung. Sinar matahari ditangkap di perangkat yang diseb ut penyuling tenaga surya di mana radiasi matahari diserap oleh air di baskom yang masih dan diubah menjadi energi panas yang menguapkan air di penyulingan. Uap yang tercipta mengembun di bagian dalam permukaan penutup yang lebih dalam dan masih tertutup oleh selokan. Ini adalah prosedur yang berlangsung bersamaan di perangkat yang sama, penyuling tenaga surya.

\subsubsection{Desalinasi Tenaga Surya Sistem Pasif Dengan Kemiringan Ganda}

Proses destilasi akan lebih efektif dengan menggunakan kemiringan ganda maka karena sinar matahari yang di terpancar dapat diterima baik dari arah timur maupun dari arah barat. 
Daerah tempat terjadi pemuaianpun jelas lebih luas yang mengakibatkan air dapat lebih cepat mencapai titik jenuh dan memuai menjadi uap dikarenakan ketebalan air yang tipis yang memungkinkan cepatnya terjadinya konduksi antara partikel-partikel air. Radiasi matahari memainkan peran penting untuk mempercepat proses penguapan di dalam penyuling tenaga surya system pasif dengan kemiringan ganda.

\subsection{Persamaan Dasar Aliran Fluida}

\subsubsection{Persamaan Pada Pompa}

Pompa adalah sebuah alat mekanik sederhana namun penting dalam menyalurkan tenaga untuk memindahkan cairan dengan laju aliran tertentu. Untuk menghitung kebutuhan daya pompa yang diguakan dalam instalasi alat, diperlukan untuk mencari beberapa factor seperti kerugian gaya gesek, kerugian karna belokan/elbow.

1.Balans energy

Jumlah energy (E) yang masuk ke sistem = Jumlah energy (E) yang keluar sistem, atau dapat dirumuskan ke dalam persamaan:

$$
\left(\mathrm{E}_{1}+\mathrm{W}_{\mathrm{P}}\right)=\left(\mathrm{E}_{2}+\Delta \mathrm{E}_{\mathrm{f}}+\Delta \mathrm{E}_{\mathrm{m}}\right)
$$

Dimana: $\mathrm{E}=$ energy

$$
\mathrm{W}_{\mathrm{P}}=\text { Daya Pompa }
$$

$\mathrm{E}_{\mathrm{f}}=$ Kerugian Energi Karena Gesekan

$\mathrm{E}_{\mathrm{m}}=$ Kerugian minor (kerugian karena belokan/elbow)

2. Persamaan Bernoulli pada pompa

$$
\begin{gathered}
\mathrm{H}_{\mathrm{p}}+\frac{P 1}{\gamma 1}+\mathrm{Z}_{1}+\frac{v 1^{2}}{2 g}=\frac{P 2}{\gamma 2}+\mathrm{Z}_{2}+\frac{v 2^{2}}{2 g}+\mathrm{H}_{\mathrm{L}} \\
\text { Dimana: } \mathrm{H}_{\mathrm{p}}=\text { Head pompa }(\mathrm{m}) \\
\frac{P}{\gamma}=\text { Head Tekanan }(\mathrm{Pa}) \\
\mathrm{Z}=\text { Head Statis total }(\mathrm{m}) \\
\frac{v^{2}}{2 g}=\text { Head kecepatan }
\end{gathered}
$$

3. Kerugian energy karena gaya gesek

Merupakan suatu kerugian aliran yang disebabkan oleh adanya gesekan antara fluida dengan dinding saluran pipa lurus. Besarnya head loss mayor dapat dihitung dengan persamaan Darcy-Weysbach sevagai berikut:

$$
\begin{aligned}
\Delta \mathrm{E}_{\mathrm{f}}=\mathrm{f} \frac{L}{D i}+\frac{V 2}{2 g} & \ldots \ldots \ldots \ldots \ldots \ldots \ldots \ldots \ldots \ldots \ldots \ldots \ldots \ldots \\
\text { Dimana: } \mathrm{f} & =\text { koefisien kerugian gesek } \\
\mathrm{L} & =\text { Panjang Pipa }(\mathrm{m}) \\
\mathrm{D} & =\text { Diameter dalam pipa }(\mathrm{m}) \\
\mathrm{V} & =\text { Kecepatan Aliran fluida }(\mathrm{m} / \mathrm{s}) \\
\mathrm{g} & =\text { percepatan gravitasi }\left(\mathrm{m} / \mathrm{s}^{2}\right)
\end{aligned}
$$

besarnya nilai $\mathrm{f}$ dapat diketahui dari jenis aliran yang terjadi. Unutk aliran laminar, besarnya koefisien gesek (f) dapat dihitung dengan persamaan

$$
\mathrm{f}=\frac{64}{\mathrm{Re}}
$$

untuk aliran turbulen, besarnya koefisien gesek (f) dapat dihitung dengan persamaan Darcy. Rumus ini berlaku atas dasar kerugian head untuk panjang pipa ratusan meter.

$$
\mathrm{f}=0.020+\frac{0.0005}{D}
$$

Dimana: $\mathrm{D}=$ diameter dalam Pipa

Nilai $f$ dapat juga dicari dengan menggunakan diagram Moody dengan menarik garis harga $R_{e}$ diplotkan dengan harga Relative Roughness $\left(\frac{\varepsilon}{D}\right)$

\section{Head loss minor}


Kerugian yang disebaban oleh adanya gesekan yang terjadi pada komponen tambahan seperti elbow, katup dan lainnya sepanjang jalur pemipaan. Besarnya head loss minor tergantung dari koefisien tahanan (f) asesoris yang digunakan.

$$
\mathrm{H}=\mathrm{f} \frac{V 2}{2 g} \text {. }
$$

Dimana $: \mathrm{f}=$ koefisien kerugian gesek

$\mathrm{V}=$ kecepatan aliran fluida $(\mathrm{m} / \mathrm{s})$

$\mathrm{g}=$ percepatan gravitasi $\left(\mathrm{m} / \mathrm{s}^{2}\right)$

\section{HASIL DAN PEMBAHASAN}

3.1 Desain Alat

Desalinasi pada dasarnya merupakan proses untuk mendapatkan air bersih dari penyulingan air laut atau air kotor. Prinsip kerja desalinasi secara umum sangatlah sederhana. Air laut atau air kotor dipanaskan di evaporator, kemudian air akan menguap dan terjadi kondensasi, yang kemudian air kondensat akan ditampung di wadah penampung yang merupakan air bersih.

Untuk penelitian kali ini, penulis melakukan penelitian desalinasi seperti penelitian yang dilakukan sebelumnya akan tetapi dengan penambahan air sebagai pendingin kaca luar. Dengan pendinginan kaca, maka proses kondensasi akan berlangsung lebih cepat dan menghasilkan lebih banyak air bersih. Berikut dibawah ini desain dari rancang bangun alat dengan menggunakan software Autocad Mechanical 2016.

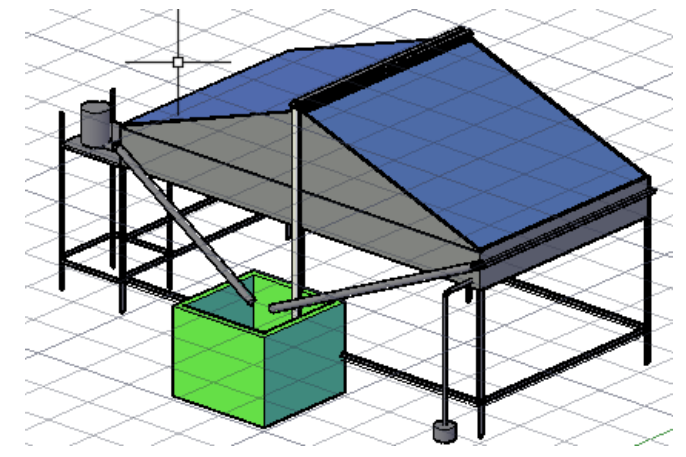

Gambar 3.1 Desain Sistem

3.1.1 Rancang Bangun Alat

Proses pengujian dilakukan dengan prosedur sebagai berikut:

1. Instalasi alat penelitian

2. Pengecekan kebocoran dan pelapisan isolasi pada evaporator

3. Mengisi air laut pada evaporator sedalam $20 \mathrm{~mm}$

4. Instalasi pipa air pendingin, pompa dan juga photovoltaic untuk daya pompa dan pengisian air pendingin pada box air

5. Proses perekaman data pada termokopel dan HOBO Micro Station Data Logger

6. Pengujian dilakukan selama 10 jam, yaitu mulai dari jam 08.00 sampai 18.00 WIB

7. Tinggi air laut pada evaporator dijaga $20 \mathrm{~mm}$

8. Pengukuran laju produksi air bersih setiap setengah jam

9. Pengujian dilkakukan selama 5 hari

10. Melakukan analisis data hasil pengujian 


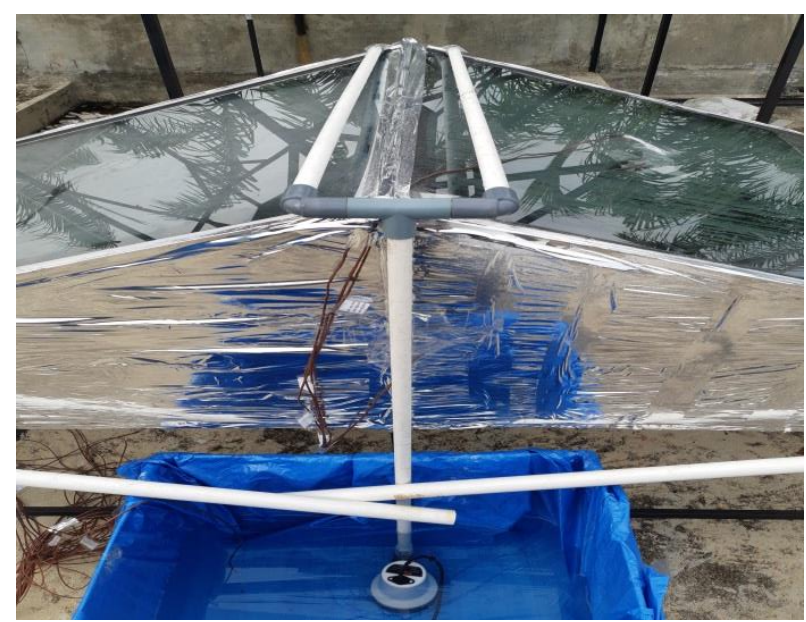

Gambar 3.2Alat jadi

\subsubsection{Set Up Eksperimental}



Gambar 3.3 Set Up Eksperimental

\subsection{Kuantitas Air Bersih Yang Diperoleh}

Dari hasil percobaan yang dilakukan selama 5 hari, jumlah air bersih yang dihasilkan hasil desalinasi dengan alat dengan pendinginan kaca luar terdapat pada tanggal 26 Juni 2019 yaitu sebanyak $4410 \mathrm{ml}$ dan hasil air bersih pada alat tanpa pendingin yaitu sebanyak $2740 \mathrm{ml}$. Laju produksi air bersih dapat dipengaruhi oleh beberapa factor seperti naik turunnya temperatur yang signifikan seperti cuaca, kelembaban udara, intensitas radiasi matahari, dan suhu lingkungan.

Perbandingan hasil air bersih yang dihasilkan selama 6 hari daapat dilihat pada Gambar 3.2. Dapat dilihat, Volume air bersih dengan alat pendingin kaca luar lebih besar dibandingan alat tanpa pendingin kaca luar. 




Gambar 3.4 Diagram Perbandingan Kuantitas Air

Dari data produksi air bersih dapat dibuat persentase perbandingannya sebagai contoh data pengujian prosuksi air bersih pada 8 Juli dimana prosuksi air bersih Alat dengan pendingin kaca luar sebayak $3800 \mathrm{ml}$ dan Alat tanpa pendingin kaca sebanyak $2360 \mathrm{ml}$ dimana terdapat selisih sebanyak $1440 \mathrm{ml}$.

Maka persentase produksi air bersih Alat 1 dengan Alat 2:

$$
\begin{aligned}
& \frac{2360}{3800} \times 100 \%=62,105 \% \text {, dimana persentase produksi air alat } 1 \text { yaitu: } \\
& 100 \%-62,105 \%=37.89 \%
\end{aligned}
$$

Dari hasil perhitungan tersebut, maka Alat desalinasi dengan pendingin kaca luar dapat memproduksi 37,86\% air bersih lebih banyak dibandingkan alat tanpa pendingin kaca. Berikut ditampilkan data pengujian produksi air bersih setiap setengah jam untuk perbandingan kedua alat.

Tabel 3.1 Produksi Air Setiap Setengah Jam

\begin{tabular}{|c|c|c|}
\hline Waktu & $\begin{array}{c}\text { Alat I } \\
\text { (ml ) }\end{array}$ & $\begin{array}{c}\text { Alat } \\
\text { II } \\
(\mathbf{m l})\end{array}$ \\
\hline $\begin{array}{c}\mathbf{7 / 8 / 1 9} \\
\mathbf{8 . 0 0}\end{array}$ & 0 & 0 \\
\hline $\begin{array}{c}7 / 8 / 19 \\
8.30\end{array}$ & 0 & 0 \\
\hline $\begin{array}{c}7 / 8 / 19 \\
9.00\end{array}$ & 0 & 0 \\
\hline $\begin{array}{c}7 / 8 / 19 \\
9.30\end{array}$ & 55 & 20 \\
\hline $7 / 8 / 19$ & & \\
10.00 & 80 & 35 \\
\hline $7 / 8 / 19$ & & \\
10.30 & 160 & 90 \\
\hline $7 / 8 / 19$ & & \\
11.00 & 180 & 90 \\
\hline $7 / 8 / 19$ & & \\
11.30 & 250 & 170 \\
\hline $7 / 8 / 19$ & & \\
12.00 & 280 & 180 \\
\hline \multicolumn{2}{|l}{} \\
\end{tabular}




\begin{tabular}{|c|c|c|}
$7 / 8 / 19$ & & \\
12.30 & 340 & 180 \\
\hline $7 / 8 / 19$ & & \\
13.00 & 510 & 300 \\
\hline $7 / 8 / 19$ & & \\
13.30 & 360 & 160 \\
\hline $7 / 8 / 19$ & & \\
14.00 & 270 & 200 \\
\hline $7 / 8 / 19$ & & \\
14.30 & 230 & 150 \\
\hline $7 / 8 / 19$ & & \\
15.00 & 180 & 150 \\
\hline $7 / 8 / 19$ & & \\
15.30 & 155 & 120 \\
\hline $7 / 8 / 19$ & & \\
16.00 & 190 & 150 \\
\hline $7 / 8 / 19$ & & \\
16.30 & 170 & 90 \\
\hline $7 / 8 / 19$ & & \\
17.00 & 150 & 100 \\
\hline $7 / 8 / 19$ & & \\
17.30 & 130 & 90 \\
\hline $7 / 8 / 19$ & & \\
18.00 & 110 & 85 \\
\hline Total & 3800 & 2360 \\
\hline
\end{tabular}

\subsection{Deskripsi Data Temperatur}

1. Grafik temperatur terhadap waktu

a. Alat 1

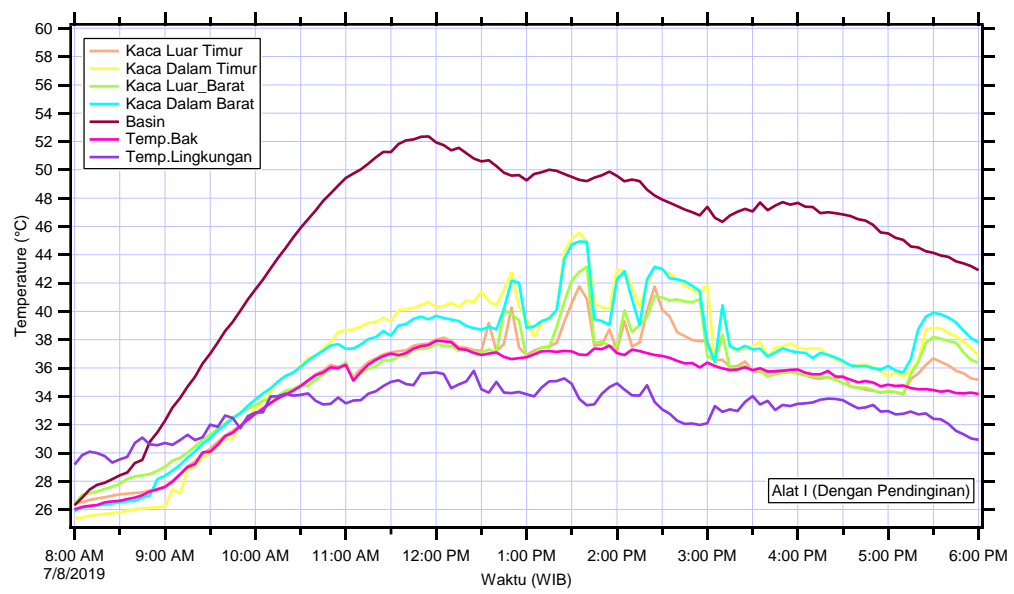

Gambar 3.5 Grafik temperatur terhadap waktu Alat 1 
b. Alat 2

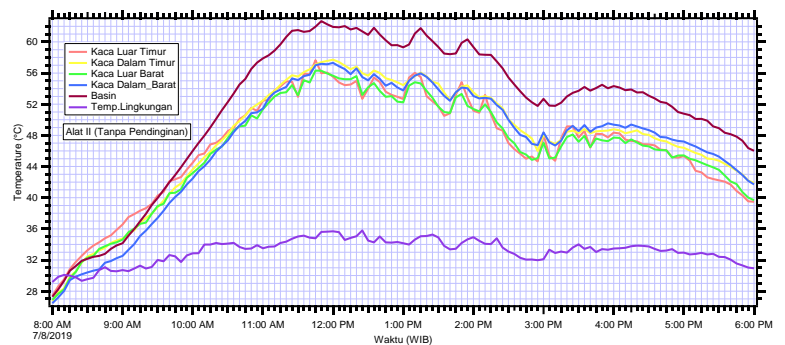

Gambar 3.6 Grafik temperatur terhadap waktu

2. Grafik produktivitas air bersih terhadap waktu

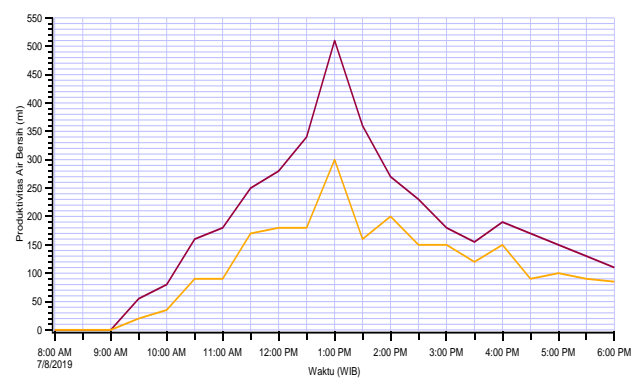

Gambar 3.7 Grafik produktivitas air bersih kedua alat terhadap waktu

3. Grafik radiasi matahari terhadap waktu

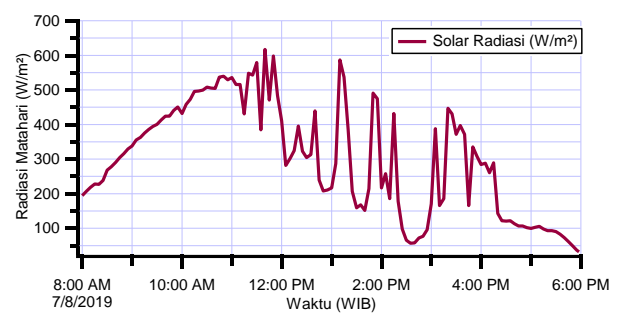

Gambar 3.8 Grafik radiasi matahari terhadap waktu

\section{KESIMPULAN DAN SARAN}

\subsection{Kesimpulan}

Adapun kesimpulan dari penelitian ini adalah:

1. Telah dirancang bangun sebuah alat desalinasi air laut dengan air sebagai pendingin kaca luar dengan pipa $3 / 4$ inci bercabang dan menggunakan pompa DC $45 \mathrm{~W}$ tenaga surya sebagai penyuplai air pendingin serta air disikluskan secara terus menerus

2. Produksi air bersih dari alat dengan pendingin kaca luar lebih banyak di setiap hari pengujian, seperti pada pengujian Tanggal 8 Juli didapat persentase Alat 1 memproduksi $37.89 \%$ air bersih lebih banyak dari Alat 2

3. Kuantitas produksi total rata -rata air bersih yang diperoleh selama pengujian 7 hari dari Alat 1 yaitu 3098,33 ml dan Alat 2 yaitu $2170 \mathrm{ml}$ 


\subsection{Saran}

Adapun saran untuk perbaikan skripsi ini adalah:

1. Untuk penelitian selanjutnya, disarankan menggunakan solar tracker untuk photovoltaic supaya pompa yang digunakan dapat terus berjalan tanpa mengatur dan menyesuaikan posisi untuk mendapatkan sinar matahari.

2. Diperlukan kabel thermocouple yang baru guna meningkatkan ketelitian pengumpulan data ketika pengujian berlangsung

\section{REFERENSI}

1. Ambarita, Himsar. 2011a. Energi Surya. Medan: Departemen Teknik Mesin FT USU.

2. Ambarita, Himsar. 2011b. Perpindahan Panas Konveksi dan Pangantar Alat Penukar Kalor. Medan: Departemen Teknik Mesin FT USU.

3. Holman, J. 1988. Perpindahan Kalor. Edisi ke-6. Jakarta: Penerbit Erlangga.

4. John A. Robertson, Clayton T. Crowe, $6^{\text {th }}$ ed, Inc.1997.Engineering Fluid Mechanics. Canada

5. Yunus, A. Cengel. 2002. Heat Transfer A Practical Approach. Second Edition. MC Graw Hill, Book Company, Inc: Singapore. 